\title{
Labour Market Transitions and Their Determinants in Slovakia: Path from Crisis to Recovery ${ }^{1}$
}

Daniel GERBERY* - Tomáš MIKLOŠOVIČ**

\begin{abstract}
The paper brings analyses of the transitions between employment, unemployment and inactivity during and after the period of the financial and economic crisis, using longitudinal micro-data from the European Union Survey on Income and Living Conditions. The empirical analysis consists of two steps. An overall picture is obtained by computing transition probabilities and Shorrocks' summary mobility index. Effects of personal and household characteristics are explored through multinomial logit models. Our results confirm the low level of labour market mobility in Slovakia and the role of some determinants highlighted by previous research. In addition, analysis takes into account several new determinants that have not been included in the previous analyses.
\end{abstract}

Keywords: labour market transitions, economic and financial crisis, longitudinal data, EU-SILC, multinomial logit regression

JEL Classification: J01, J60, J64, J82

DOI: https://doi.org/10.31577/ekoncas.2020.07.01

\section{Introduction}

The labour markets are in a constant state of flux (Mortensen and Pisarides, 1999). The study looks at these dynamics in terms of transitions between labour market statuses. Analysis of movements between employment, unemployment and inactivity can reveal what happens "behind the scene" of the labour market

* Daniel GERBERY (ORCID 0000-0002-7623-5549), corresponding author, Comenius University in Bratislava, Faculty of Arts, Department of Sociology, Gondova 2, 81499 Bratislava, Slovakia; e-mail: daniel.gerbery@uniba.sk

** Tomáš MIKLOŠOVIČ (ORCID 0000-0003-3104-0905), Institute of Economic Research, Slovak Academy of Science, Šancová 56, 81105 Bratislava, Slovakia; e-mail: tomas.miklosovic@ @avba.sk

${ }^{1}$ This work was supported by the Slovak Research and Development Agency under the contract No. APVV-17-0329. 
described by aggregate indicators. Identification of the relative role of flows in and out of various labour market statuses contributes to a better understanding of changes in unemployment and employment rates. For example, one can ask whether a decline in unemployment rate results from an increase in the transitions from unemployment to employment, or an increase in the transitions from unemployment to inactivity. The examination of transition probabilities of various socio-demographic categories can shed the light on the role of individual and household characteristics. This type of knowledge is useful both for a better understanding of labour market development and for an improving the policy design of labour market interventions (European Commission, 2016).

The aim of the paper is to identify how labour market transitions have changed during and after the recent financial crisis and what factors have played an important role. The focus is on changes in the overall level of status mobility, patterns of the labour market transitions, as well as changes in the effects of the micro-level determinants. The study contributes to existing literature by providing a detailed analysis of the country about which too little is still known when it comes to labour market transitions. Although several comparative analyses in this field included Slovakia (Bachmann et al., 2015; RWI, 2014; Ward-Warmedinger and Macchiarelli, 2014), they provided limited evidence. However, Slovakia is an interesting case as it represents a country in Central Europe that has experienced a specific labour market development, characterised by a successful diminishing of the high levels of unemployment on the one hand and by persisting labour market rigidities on the other hand. By investigating the labour market flows, it is possible to set out clearly what processes and factors were contributing to this development.

The paper is structured as follows. The first part offers a review of the recent arguments and findings regarding the labour market transitions and the role of the crisis. The second part explains the methodology of empirical analysis. Next, an empirical analysis follows. After a description of the key characteristics of the labour market in the pre-crisis and post-crisis periods, the transition matrices, and the results of regression analyses are discussed. In the final part, we discuss our results in relation to the findings from the other recent analyses.

\section{Labour Market Transitions and the Financial and Economic Crisis}

Although there are several types of labour market transitions, including movements between jobs with different characteristics, ${ }^{2}$ we focus on transitions between different labour market states: employment, unemployment, and inactivity. Labour

\footnotetext{
${ }^{2}$ They include, for example, movements from permanent to temporary contracts, from low-pad to better-paid jobs.
} 
market transitions are theoretically grounded in the search and matching model of the labour market (Mortensen and Pissarides, 1994). The basic model takes into account two labour market states - unemployment and employment - and assumes that jobseekers' search for jobs and firms' search for workers take time and are costly. As a result, the labour market frictions are unavoidable parts of the functioning of labour market and preclude the simultaneous match of jobseeker and vacancies (Ernst and Rani, 2011). To reach equilibrium, employment, unemployment, and vacancy rates should be constant. What is important is that, it requires flows between the two labour market states to be constant too. Here, firms' decisions regarding vacancies, jobseekers' decisions regarding job acceptance, and destruction of jobs matches, which can take exogenous or endogenous form, represent contributing factors (RWI, 2014). Within this framework, the effects of business cycles or labour market institutions, as well as other factors can be examined.

According to the latest OECD study (Garda, 2016), which covers the period between 2005 and 2012, the annual transition rate from employment into joblessness (unemployment or inactivity) averaged 10\% across OECD countries. The average annual transition rate for movements in an opposite direction represented 30\%. ${ }^{3}$ Employment instability was far from negligible: $18 \%$ of workers, who moved from employment to unemployment or inactivity, did so twice or more. Of course, there are significant cross-country differences behind these figures. The cross-country variation reflects the differences in institutional frameworks of the labour markets, in particular the differences in regulation constraints and labour market policies. Unsurprisingly, the countries with less rigid labour markets show higher transition probabilities in and out of employment. This also holds true for the countries with a lower degree of rigidity of the product markets, as the product market regulations ${ }^{4}$ influence entries and exits of firms (and new hiring and layoffs), which account for one third of the all workers' flows (Garda, 2016). Furthermore, a higher frequency of labour market transitions relates to more generous unemployment benefits and higher spending on the active labour market policies.

The labour market dynamics were hit by the financial and economic crisis. One of the first attempts to identify the main patterns of the change was the analysis carried out on behalf of the European Commission immediately after the crisis (RWI, 2014). This shows that it was transitions between employment and unemployment, which was changed substantially during the recession: employment stability was significantly reduced, and transitions from employment

\footnotetext{
${ }^{3}$ The probability of moving from employment to unemployment was similar to the probability of entering inactivity. The probability of becoming employed was higher for unemployed (46\%) than for inactive persons (20\%).

${ }^{4}$ For example, costs related with starting a business.
} 
to unemployment increased in the EU member states. Temporary contracts played an important role in this respect as the crisis induced a strong increase in movements from temporary employment to unemployment. At the same time, there was an increasing tendency among unemployed to move to education and inactivity, accompanied by decreasing probability to move to employment. As a result, it was the increase in flows from employment to unemployment that contributed most significantly to the overall unemployment growth and not the decrease the flows out of unemployment.

The study also reveals heterogeneous effects on different socio-demographic groups. As regards transitions from employment to unemployment (and particularly transitions from temporary employment to unemployment), men and young workers were more negatively affected. When it comes to an opposite flow from unemployment to employment, men showed higher probability to remain in unemployment and a lower probability to move into employment as compared to women. On the other hand, women more often moved from unemployment to inactivity (RWI, 2014). Studies at a country level also confirm a differential impact across various socio-demographic and socio-economic categories (Bergin, Kelly and McGuinness, 2015; Lehmann, Razzolini and Zaiceva, 2015).

Bachmann et al. (2015) pointed to the heterogeneous effects of the crisis on the EU countries. In terms of the "standard" clusters of countries, the Anglo-Saxon countries showed a specific trajectory during the crisis. They experienced the strongest decline in employment stability, the strongest increase in transitions from employment to unemployment, and a disproportional increase in transitions to inactivity. Other country clusters, including countries from Central and Eastern Europe, followed these trends as well, but they did not display such strong effects. ${ }^{5}$ As these authors argue (2015, p. 26), the cross-country (and cross-cluster) variability is driven by differences in the institutional settings of the labour markets, with the dominant role of employment protection.

The majority of the research focuses on the first phase of the crisis between 2008 and 2010/2011. Later developments were covered, for example, by the European Commission's study (2016), which shows that labour markets were not frozen in the second phase of the crisis, but that they experienced quite strong dynamics. Later, until mid-2013, unemployment in the EU grew despite the fact that the flows from unemployment to employment outnumbered the flows in the opposite direction. The reason was increasing flows of transitions

${ }^{5}$ Prior the crisis, the situation was quite different, as Ward-Warmedinger and Macchiarelli (2014) showed. The CEE, including Slovakia, and Mediterranean countries faced several difficulties. They experienced decrease in the overall labour market mobility (which increased in the Continental and Nordic countries), they displayed weak transitions from unemployment and inactivity into employment and increase in the probability to remain in unemployment. 
from inactivity to unemployment. At the same time, a decline in employment resulted from the fact that the flows from joblessness to employment were overweighed by the transitions from employment to joblessness (European Commission, 2016). The study also confirms an increased role of temporary contracts in most EU Member States during the crisis, including in its second phase. However, temporary jobs became "career dead ends" for many workers, as transitions to permanent contracts deteriorated.

\section{Labour Market in Slovakia prior and after the Financial and Economic Crisis}

In the years before the crisis, Slovakia experienced strong economic and employment growth. Since 2005, the GDP growth rate was one of the highest among the EU countries, reaching $10.8 \%$ in 2007 . Unemployment fell considerably from $16.4 \%$ in 2005 to $11.2 \%$ in 2007 . Long-term unemployment followed a similar trajectory, dropping from $11.5 \%$ to $8.3 \%$. All other main labour market indicators also improved. On the other hand, despite the positive development, unemployment and long-term unemployment rates were still high, far above the EU average. The same applies for the share of long-term unemployment on total unemployment, which remained above $70 \%$ during the period.

The crisis hardly hit the Slovakian labour market. Although the GDP decline was comparable to that of neighbouring countries like Hungary or Czech Republic, the unemployment rate in Slovakia increased more significantly (D'Apice, 2014, p. 2). Unemployment (14.5\% in 2010), long-term unemployment $(9.2 \%)$ and youth unemployment $(33.9 \%)$ were among the highest in the EU. The crisis has amplified existing structural imbalances in the labour market and, at the same time, it has undermined the achievements of the previous period of economic boom.

The first years of the post-crisis period brought positive developments accompanied by persisting structural problems. Although the overall economic recovery from the recession was one of the strongest in the EU (OECD, 2012), the labour market lagged behind. Employment growth did not correspond to the dynamics of the GDP growth and was erratic and uneven over the years, including 2013 (Hvozdíková and Studená, 2016). Despite some positive trends - reduction in unemployment rate (14\% in $2012,13.2 \%$ in 2014) - high levels of unemployment as well as long-term unemployment continued to be a typical feature of the Slovak labour market. It is only since 2014, when labour market has started to recover fully in terms of strong economic growth, strong employment growth and a significant reduction in unemployment (Figure 1). On the other hand, structural problems have persisted, including huge regional disparities, weak 
labour market attachment of low skilled, skill mismatches, and low employment rate of mothers with small children, and strong effects of the social background on education and labour market outcomes.

Figure 1

Recent Trends in the Slovak Labour Market (\%)

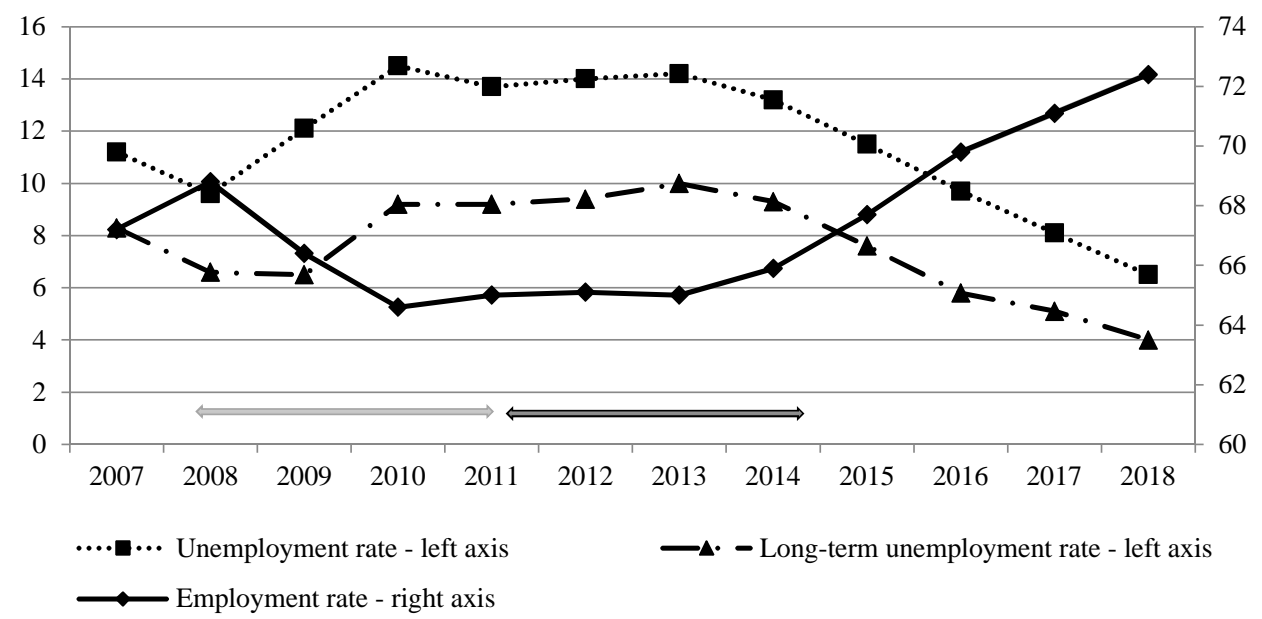

Source: Eurostat.

In terms of labour market transitions, the labour market in Slovakia was characterised by a low degree of labour market mobility prior to the recession. The Shorrock's mobility index represented 0.221 in the period $2004-2008$, which was one of the lowest values among the EU countries (Flek and Mysíková, 2015; Garda, 2016; Ward-Wardeminger and Macchiarelli, 2014). Decline in the unemployment rate was mainly a result of the net flow from unemployment to employment; other flows played only minor role (Flek and Mysíková, 2015). In a comparative perspective, the labour market in Slovakia showed a higher capacity to absorb the least qualified and older workers than the labour markets in the Czech Republic and Poland (ibid.). As regards labour market transitions in the post-crisis years, we are not aware of any analysis that focuses on the situation in Slovakia. The paper aims, inter alia, to fill this gap.

\section{Data and Methodology}

When analysing labour market transitions, longitudinal micro-data are typically used. The empirical studies on labour market transitions in the EU countries, whether comparative or not, are usually based on data from the European 
Union Labour Force Survey (EU-LFS) or the European Union Survey on Income and Living Conditions (EU-SILC). Some comparative studies employ both data sources in order to validate results (see, for example, RWI, 2014). Our analysis relies on the EU-SILC longitudinal data due to several reasons. The EU SILC has a longitudinal component that allows for following respondents over a fouryear period. ${ }^{6}$ Unlike the EU-LFS, it offers annual as well as monthly information on labour market statuses (transitions). It also contains more information on individual and household characteristics that can be tested as determinants of various transitions.

We use two longitudinal datasets: EU-SILC 2008 - 2012 and EU-SILC 2012 - 2015. The first dataset refers to the years $2007-2011$, covering the period shortly before and after the onset of the economic and financial crisis. The second dataset refers to the years 2011 - 2014 and captures the period after the crisis, which was characterised by slow recovery. In both datasets, we focus on persons aged $16-65$ years who were surveyed for at least two consecutive years.

In the EU SILC, labour market status refers to a "self-declared main activity status". This means that it captures the person's own perception of his/her main activity. As such, it differs from the ILO concept (Eurostat, 2017). We use monthly information on main activity, captured in the variable PL211X, which is retrospectively reported for the income reference period. Based on monthly main activity, we define three types of labour market states: employment, unemployment, and inactivity.

Labour market transitions refer to movements between these labour market states. Transitions are calculated as respondents' movements between labour market status in a given month and labour market status in the same month in the following year (for example, movements between labour market statuses in January 2008 and January 2009). Given the fact that we use a four-year panel, information about 48 monthly labour states are available for each surveyed respondent. Based on this, we deal with data on 36 labour market transitions for each respondent.

The strategy of empirical analysis consists of two main elements. Firstly, we provide an overall picture on labour market transitions in terms of transition probabilities. Probabilities of transitions from labour market states at time point $t$ to other ones at time point $t+1$ are expressed in the form of Markov transition matrix. In this matrix, transition probabilities are modelled using Markov transition

\footnotetext{
${ }^{6}$ The longitudinal EU-SILC takes the form of a four-year rotational panel in which each subsequent year the one quarter of total sample is replaced by a new sub-sample of respondents.

${ }^{7}$ It may seem that the dataset EU-SILC 2008 - 2012 does not cover the period of the crisis properly, as it includes the pre-crisis year 2007. However, as we focus on annual changes, we capture labour market transition between year 2007 and year 2008, when the crisis began.
} 
chains, which suppose that the distribution of variable $v$ in period $t+1$ is determined by the distribution of this variable in the previous period $t$ (RWI, 2014, p. 40). The formal expression can be written as

$$
P R\left[v_{t+1}=v \mid v_{t}, v_{t-1}, \ldots, v_{0}\right]=P R\left[v_{t+1}=v \mid v_{t}\right]
$$

When we apply this general formula, for example, to transition from inactivity (i) in time $t$ to employment (e) in time $t+1$, the probability of such transition would equal to:

$$
P R\left[e_{t+1}=e \mid i_{t}=i\right]
$$

As we consider movements between three labour market states, Markov transition matrix contains three rows and three columns, where the diagonal elements represent unchanged labour market states.

An overall picture on labour market transition is supplemented by the Shorrocks' summary index of labour market mobility, which captures the probability of moving across given number of labour market statuses between two points in time ( $t$ and $t+1$ ). The mobility index is bounded between 0 and 1 , where the value of zero implies no mobility (i.e. no probability of leaving any labour market status) and value of one implies full mobility (Ward-Wardeminger and Macchiarelli, 2014). It takes the following form:

$$
M=[n-\operatorname{tr}(Q)] /(n-1)
$$

where

$n \quad-$ denotes the number of labour market statuses,

$\operatorname{tr}(Q) \quad$ - refers to the trace of the transition matrix.

We will calculate the summary index of labour mobility for the total population, as well as for various socio-demographic categories.

Secondly, we estimate several multinomial logit models in order to investigate the effects of personal and household characteristics on labour market transitions. We estimate models for transitions from three labour market states: employment, unemployment, and inactivity. In each case, there are also three destination states. For example, in the case of transition from employment, we estimate probability of transition to unemployment, inactivity, or probability of remaining in employment.

The multinomial logit model with the vector of personal and household characteristics $X$ takes the following general form (RWI, 2014, p. 43):

$$
\ln \Omega_{m \mid b}=\ln \left\{\frac{\operatorname{Pr}(y=m \mid X)}{\operatorname{Pr}(y=b \mid X)}\right\}=X \beta_{m \mid b}, \text { with } m=1,2, \ldots, j
$$


In this equation, $b$ represents a base (reference) category, $m$ is an actual status, and $\ln \Omega_{m / b}$ refers to log-odds of being in status $\mathrm{m}$, compared to the base (reference) status.

We interpret the relationship between explanatory variable(s) and dependent variable in terms of predicted probabilities. The general form of predicted probability from multinomial logit model can be expressed as (Bachmann et al., 2015)

$$
\operatorname{Pr}(y=m \mid x)=\exp \left(x \beta_{m \mid b}\right) / \sum_{i=1}^{j} \exp \left(x \beta_{i \mid b}\right), \text { with } m=1,2, \ldots, j
$$

Here, $\beta_{i \mid b}$ is the coefficient vector, which contains the intercept and the slope coefficients. Thus, there is one set of coefficients for each alternative status. In order to guarantee identification of the model, the coefficient vector for the base category is set to zero (Wulff, 2015). All other results are then interpreted relative to this base category.

The list of explanatory variables includes micro-level factors that have usually been tested in the studies on labour market transitions, as well factors that plays an important role when it comes to the Slovak labour market (Štefánik et al., 2018). It contains "usual" socio-demographic variables like age, sex, health status, marital status, and number of children in the household. In addition, we are interested in the effects of position in the labour market (type of contract, occupational categories); household's situation in relation to the labour market (household's work intensity) and place of living (degree of urbanisation, region).

We run six multinomial logit models. Three models, which model transitions from three labour market statuses - employment, unemployment and inactivity, are estimated for the crisis period 2008 - 2011 (based on the EU-SILC dataset 2009 - 2012). The other three models, with the same specifications, are estimated for the post-crisis period 2011 - 2014 (the EU-SILC dataset 2012 - 2015).

In the first model, a nominal variable "transitions from employment", consisting of three categories (transition from employment to employment, unemployment, and inactivity), serves as a dependent variable. In the second model, a variable "transitions from unemployment" is modelled. The third model contains "transitions from inactivity" as a dependent variable. All models include the same list of explanatory variables. Marginal effects with their standard errors are reported in tables in the annex. ${ }^{8}$

Each table refers to the results of one multinomial model and contains three columns that represent three destination states (employment, unemployment, inactivity).

\footnotetext{
${ }^{8}$ Annex is available online at the website of Journal of Economics.
} 


\section{Transitions between Labour Market Statuses in Slovakia during and after the Recession}

Markov transition matrices for the crisis and post-crisis years show (Table 1) three main features of the labour market mobility. Firstly, the stability of jobs has slightly increased. During the crisis, almost $95 \%$ of workers who were employed in the previous year were still employed in the subsequent year. In the post-crisis period, this percentage increased to $95.7 \%$. The transition rate for the movements from employment to unemployment has changed in the opposite direction.

Secondly, the resilience of unemployment, which manifested itself after the recession, comes from two sources: from the significant increase in the probability of remaining in unemployment (from $64.9 \%$ during the crisis, to $70.3 \%$ in the period after the crisis), and from the significant decline in the unemployment-to-employment transition rate (from $29.8 \%$ to $24.7 \%$ ). Thirdly, the transition rates for flows from inactivity to other labour market statuses prior the crisis are almost identical to rates after the crisis. The low level of mobility among persons outside of the labour force indicates one of the main problems the Slovak labour market has had to face.

Table 1

Markov Transition Matrix for the Crisis Period and Post-Crisis Period Average Annual Probabilities of Transitions (\%)

\begin{tabular}{|l|c|c|c|c|c|c|}
\hline \multirow{2}{*}{ Origin } & \multicolumn{5}{|c|}{ Destination } \\
\cline { 2 - 7 } & Employment & Unemployment & Inactivity & Employment & Unemployment & Inactivity \\
\cline { 2 - 7 } & \multicolumn{3}{|c|}{ Crisis period (2007-2011) } & \multicolumn{2}{c|}{ Post-crisis period (2011-2014) } \\
\hline Employment & 94.9 & 3.0 & 2.1 & 95.7 & 2.3 & 1.9 \\
Unemployment & 29.8 & 64.9 & 5.3 & 24.7 & 70.3 & 5.1 \\
Inactivity & 2.8 & 2.1 & 95.1 & 2.7 & 2.0 & 95.3 \\
\hline
\end{tabular}

Source: EU-SILC 2009 - 2012 and 2012 - 2015, authors' calculations.

There are differences in the transition rates between men and women as Table 2 shows. Flows from unemployment during the crisis represent one example. While men and women had similar probability to move from unemployment to employment, women had higher probability to move from unemployment to inactivity (6.4\% vs. $4.3 \%)$. The hypothesis is that unemployed women tended more often to engage in family-related activities in order to avoid the limited prospects in the labour market. This is partly confirmed by the fact that women remained more frequently trapped in inactivity than men (95.6\% vs. $94.4 \%)$ in this period. On the other hand, women had lower probability of remaining in unemployment (63.6\% vs. $66.1 \%)$. 
In the post-crisis period, the prospects of unemployed persons have further deteriorated, and unemployed women were hit harder. Their unemployment-to-employment transition rate fell by almost six percentage points to $24.1 \%$. The male transition rate declined by 4.3 percentage points and reached $25.3 \%$. At the same time, the "immobility" of unemployed persons has become more frequent among men and women - but to a different extent. For men, the probability of staying in unemployment from one year to the next has increased by 3.5 percentage points to $69.6 \%$. For women, the probability has jumped by 7.3 percentage points to $70.9 \%$. As a result, the gender gap observed in the crisis period has almost disappeared.

T a b l e 2

Markov Transition Matrices for Men and Women - Average Annual Probabilities of Transitions for Men and Women (\%)

\begin{tabular}{|c|c|c|c|c|c|c|}
\hline \multirow[t]{3}{*}{ Origin } & \multicolumn{6}{|c|}{ Destination } \\
\hline & Employment & Unemployment & Inactivity & Employment & Unemployment & Inactivity \\
\hline & \multicolumn{3}{|c|}{ Crisis period $(2007-2011)$} & \multicolumn{3}{|c|}{ Post-crisis period $(2011-2014)$} \\
\hline \multicolumn{7}{|l|}{ Male } \\
\hline $\begin{array}{l}\text { Employment } \\
\text { Unemployment } \\
\text { Inactivity }\end{array}$ & $\begin{array}{r}94.5 \\
29.6 \\
3.2 \\
\end{array}$ & $\begin{array}{r}3.3 \\
66.1 \\
2.4 \\
\end{array}$ & $\begin{array}{r}2.2 \\
4.3 \\
94.4 \\
\end{array}$ & $\begin{array}{r}95.5 \\
25.3 \\
3.4 \\
\end{array}$ & $\begin{array}{r}2.7 \\
69.6 \\
2.6 \\
\end{array}$ & $\begin{array}{r}1.9 \\
5.0 \\
94.0 \\
\end{array}$ \\
\hline \multicolumn{7}{|l|}{ Female } \\
\hline $\begin{array}{l}\text { Employment } \\
\text { Unemployment } \\
\text { Inactivity }\end{array}$ & $\begin{array}{r}95.2 \\
30.0 \\
2.6\end{array}$ & $\begin{array}{r}2.8 \\
63.6 \\
1.8 \\
\end{array}$ & $\begin{array}{r}2.0 \\
6.4 \\
95.6 \\
\end{array}$ & $\begin{array}{r}96.0 \\
24.1 \\
2.2 \\
\end{array}$ & $\begin{array}{r}2.0 \\
70.9 \\
1.6\end{array}$ & $\begin{array}{r}2.0 \\
5.0 \\
96.2 \\
\end{array}$ \\
\hline
\end{tabular}

Source: EU-SILC 2009 - 2012 and 2012 - 2015, authors' calculations.

Previous research pointed to the crisis's effects on the labour market transitions of the youngest persons. Our analyses confirm that flows from employment to unemployment were observed mainly among the youngest cohort (Table 3). On the other hand, the older workers aged 54 to 64 displayed the lowest probability of staying in employment from one year to the next and the highest probability of moving from employment to inactivity. After the crisis, the oldest cohort has remained the most fragile in terms of flows from employment to inactivity after the crisis.

This "inactivity bias" of the oldest age category is even stronger when it comes to the movements from unemployment. Moreover, once in inactivity, it was very difficult for persons aged 55 to 64 to escape from it. They displayed the highest probability of staying in inactivity in both periods. It was so high that it almost crowded out all flows from inactivity to employment and unemployment. These transition rates partly reflect retirements and early retirements in given age category. 
The period after the recession has brought yet another problem for persons aged 55 to 64 . Persistence of unemployment has grown by 7.6 percentage points, representing the largest increase among all age categories, and reached $75.1 \%$. This fact, together with a marked decline in the probability of moving from unemployment to employment, has weakened job prospects of the unemployed.

T a ble 3

Markov Transition Matrices for Different Age Categories Average Annual Probabilities of Transitions (\%)

\begin{tabular}{|c|c|c|c|c|c|c|}
\hline \multirow[t]{3}{*}{ Origin } & \multicolumn{6}{|c|}{ Destination } \\
\hline & Employment & Unemployment & Inactivity & Employment & Unemployment & Inactivity \\
\hline & \multicolumn{3}{|c|}{ Crisis period $(2007-2011)$} & \multicolumn{3}{|c|}{ Post-crisis period $(2011-2014)$} \\
\hline \multicolumn{7}{|l|}{$16-24$ years } \\
\hline Employment & 91.1 & 6.8 & 2.1 & 93.0 & 4.0 & 3.0 \\
\hline Unemployment & 29.5 & 61.1 & 9.4 & 29.9 & 63.2 & 6.9 \\
\hline Inactivity & 3.9 & 4.3 & 91.8 & 4.1 & 4.7 & 91.2 \\
\hline \multicolumn{7}{|l|}{$25-34$ years } \\
\hline Employment & 96.4 & 3.3 & 0.3 & 97.0 & 2.8 & 0.2 \\
\hline Unemployment & 38.7 & 58.8 & 2.4 & 32.5 & 63.9 & 3.6 \\
\hline Inactivity & 20.2 & 9.9 & 69.9 & 19.2 & 10.4 & 70.4 \\
\hline \multicolumn{7}{|l|}{$35-44$ years } \\
\hline Employment & 96.5 & 3.1 & 0.4 & 97.8 & 2.0 & 0.2 \\
\hline Unemployment & 31.1 & 67.6 & 1.2 & 25.2 & 74.3 & 0.5 \\
\hline Inactivity & 2.5 & 2.9 & 94.6 & 2.5 & 2.0 & 95.5 \\
\hline \multicolumn{7}{|l|}{$45-54$ years } \\
\hline Employment & 96.9 & 2.5 & 0.6 & 97.3 & 2.3 & 0.5 \\
\hline Unemployment & 25.5 & 71.9 & 2.6 & 22.1 & 75.2 & 2.7 \\
\hline Inactivity & 3.4 & 0.4 & 96.2 & 6.8 & 0.4 & 92.8 \\
\hline \multicolumn{7}{|l|}{55 - 64 years } \\
\hline Employment & 88.6 & 2.9 & 8.5 & 90.1 & 2.2 & 7.7 \\
\hline Unemployment & 17.5 & 67.5 & 15.0 & 11.1 & 75.1 & 13.8 \\
\hline Inactivity & 0.8 & 0.1 & 99.1 & 0.7 & 0.2 & 99.1 \\
\hline
\end{tabular}

Source: EU-SILC 2009 - 2012 and 2012 - 2015, authors' calculations.

In order to capture an overall picture of labour market mobility we calculate Shorrock's index (Table 4). It reached the value of 0.226 during the recession and 0.193 in the subsequent period. The fact that the labour market has become more frozen after the recession represents a counter-intuitive finding only at first sight. Unlike the period after the recession, the crisis brought with it significant changes in the main labour market indicators, which resulted from increasing dynamics, in particular from changing transition rates of movements from employment to employment and movements in the opposite direction. Lower labour market mobility after the recession clearly stem from the increased rate of reproduction of labour market statuses. The consequences of the decline in the 
dynamics always depend on what kinds of statuses are reproduced. While increased stability of employment represents a positive trend, increased stability of unemployment or inactivity is exactly the opposite. In Slovakia, the labour market has experienced an increase in the reproduction of all labour market statuses, with the strongest growth of immobility among the unemployed.

Table 4 also depicts differences among various sub-populations. Persons with high level of education show the highest level of labour market mobility, well above the population average. On the other hand, the mobility of low-educated persons has been frozen in both periods. Looking at the magnitude of change, persons aged 35 to 44 and 55 to 64 have experienced the biggest drop. Further, high-educated persons and women also display a large decline in the overall mobility.

Ta b le 4

Shorrock's Index of Labour Market Mobility during and after the Crisis

\begin{tabular}{|l|c|c|c|}
\hline & $\begin{array}{c}\text { Crisis period } \\
(\mathbf{2 0 0 7}-\mathbf{2 0 1 1})\end{array}$ & $\begin{array}{c}\text { Post-crisis period } \\
\mathbf{( 2 0 1 1} \mathbf{- 2 0 1 4 )}\end{array}$ & $\begin{array}{c}\text { Percentage change } \\
\mathbf{( \% )}\end{array}$ \\
\hline Men & 0.225 & 0.204 & 9.3 \\
Women & 0.228 & 0.185 & 18.9 \\
16-24 years & 0.280 & 0.263 & 6.1 \\
25 - 34 years & 0.374 & 0.344 & 8.0 \\
35 - 44 years & 0.206 & 0.162 & 21.4 \\
45 - 54 years & 0.175 & 0.173 & 1.1 \\
55 - 64 years & 0.224 & 0.178 & 20.5 \\
Low level of education & 0.128 & 0.113 & 11.7 \\
Medium level of education & 0.234 & 0.204 & 12.8 \\
High level of education & 0.393 & 0.318 & 19.1 \\
\hline Total population & 0.226 & 0.193 & 14.6 \\
\hline
\end{tabular}

Source: EU-SILC 2009 - 2012 and 2012 - 2015, authors' calculations. The index is bounded between 0 and 1 .

\subsection{Determinants of Labour Market Transitions during the Crisis Period}

Taking into account significant coefficients in Tables A1 to A3, several patterns emerge. The regression results confirm that education plays an important role. As regards employed persons (Table A1), the chances of remaining in employment during the crisis years were highest for those with high level of education. They were 8.7 percentage points more likely to remain employed than low-educated persons. On the other hand, employed persons with high level of education were less likely to become unemployed (by 5.4 percentage points) and inactive (by 3.4 percentage points) than low-educated employed persons.

When it comes to transitions from unemployment (Table A2), education had an even stronger effects. High-educated unemployed persons found it much easier to move to employment: their chance of moving from unemployment to employment 
was 16.1 percentage points higher, as compared to that of low-educated unemployed. At the same time, their probability of remaining in unemployment was much lower (21.1 percentage points). As regards transitions from inactivity, the higher level of education correlates with the lower probability of remaining in inactivity.

Other strong determinants of transitions include characteristics related to work (length of work experience, type of occupation, type of contract) and labour market attachment (work intensity). During the crisis years, more experienced workers had higher probability of remaining in employment. Workers who had worked for 16 years or more were 8.3 percentage points more likely to maintain employment, as compared to workers with 5-year or shorter work experience. This also holds true for workers who worked for $11-15$ years (4.5 p.p.) and for 6 - 10 years (2.9 p.p.). Length of work experience also differentiates the probability of moving from employment into unemployment: the shorter work experience the higher probability of becoming unemployed during the crisis. The same applies to transitions from employment to inactivity.

Length of work experience had stronger effects on transitions of unemployed persons. More experienced persons had higher chances to move into employment and lower chances to remain in unemployment during the crisis years. For example, the unemployed who had worked for 16 years or more were 8.2 percentage points more likely to find a job and almost 13 percentage points less likely to stay unemployed, compared to the unemployed with the shortest work experience (5 years or less). On the other hand, the unemployed with longer work experience had a higher probability of transitioning into inactivity. We suppose it was older workers (with more years spent in work) who withdrew more frequently from the labour market and entered inactivity.

Part-time workers did better in some respects than workers in full-time jobs. Being a part-time worker meant a higher probability of remaining in employment (by 2.4 p.p.) and a lower probability of moving from employment to inactivity (by 3.4 p.p.). The regression results also suggest that previous involvement in part-time job positively affected the chances of unemployed persons. Unemployed persons who previously worked in part-time jobs were 7.6 percentage points more likely to find a job than the unemployed who were previously involved in full-time jobs. Furthermore, the unemployed who worked previously in part-time jobs had lower probability to remain in unemployment (by 4.5 p.p.) and a lower probability to move to inactivity (by 3.1 p.p.).

Occupational categories, captured by the ISCO-08, differ markedly in terms of transition probabilities. In general, low-level occupations (categories $6-8$ according to the ISCO-08) and elementary occupations (category 9) provided 
better chances in the labour market during the crisis. Workers in elementary occupations were 16.7 percentage points more likely to remain in employment, as compared to high-level occupations (categories $1-3$ ). The chances of workers in low-level occupations were higher by 10.8 percentage points. Both occupational groups showed lower probability to move from employment to unemployment and inactivity. It seems that the crisis years worsened job prospects especially for workers at the top of the occupational ladder.

The category of occupation plays an important role in the movements from inactivity. Inactive persons who previously worked in high-level occupations showed the lowest probability to move into employment or unemployment. Further, they were more likely to stay inactive, as compared to other occupational groups. Persons whose last job belonged to elementary occupations had better labour market prospects (i.e. the highest chances to move from inactivity to employment) and to enter the labour force (i.e. the highest chances to move from inactivity to unemployment).

Labour market transitions were also affected by the overall household employment situation. Higher level of work intensity correlated with a higher probability of success in the labour market. Workers from the households with high work intensity were 19 percentage points more likely to stay in employment than workers who lived in the households with low work intensity. Workers who lived in households with high work intensity also had smaller chances to move to unemployment (by 9.8 p.p.) and to inactivity (by 9.2 p.p.).

Work intensity seems to be correlated with movements out of unemployment. Higher level of work intensity increased the probability of moving from unemployment to employment. Unemployed persons living in households with high level of work intensity had markedly higher chances (by 48.8 p.p.) to move to employment, as compared to unemployed in households with low work intensity. Similarly, this holds true for unemployed persons living in the households with medium work intensity: their chances to find a job were 27.6 percentage points higher compared to the chances of the unemployed in the households where almost nobody worked.

Our multinomial logit models contain also other variables. We control for sex, age, and marital status, number of children, health, region, or degree of urbanisation. Some of these variables' coefficients do have meaningful interpretation. Men had slightly better chances for success in the labour market - to stay employed or move from unemployment to employment. On the other hand, women were more likely to move to inactivity - both from employment and unemployment. Age was an important factor that differentiated probability of reproduction of unemployment, with the stronger effects in the post-crisis period. Health status 
played some role in relation to inactivity. In particular, the unemployed with worse health were more likely to move from unemployment to inactivity (by 4.3 p.p.) and inactive persons with poorer health were more likely to stay in inactivity (by 2.8 p.p.).

\subsection{Determinants of Labour Market Transitions after the Crisis}

The results for the period 2011 - 2014 are reported in Tables A4 to A6 in the annex. Compared to the period $2008-2011$, several similarities as well as differences have appeared. ${ }^{9}$ Education has ceased to affect transitions from employment in the post-crisis period. However, the effect of education has not disappeared entirely. Education has continued to play an important role in relation to transitions from unemployment. Its effects were comparable with those in the crisis period. For example, high-educated unemployed were 12.8 percentage points more likely to find a job and 18.3 percentage points less likely to stay in unemployment, compared to the unemployed with low level of education. As regards transitions from inactivity, the situation in the period 2011 - 2014 was similar to that in the period $2008-2011$. The higher level of education correlates with a lower probability of remaining in inactivity and a higher probability of moving to employment.

Length of work experience has continued to differentiate probabilities of transitions from all three labour market states. In particular, it affected the probability to find a job among unemployed persons and a probability to stay in unemployment. Unemployed persons with longer work experiences had higher chances to move to employment and a lower probability to stay unemployed. For example, unemployed persons with long work experience (more than 15 years) were 19.7 percentage points more likely to find a job than unemployed persons who had short work experience (5 years or less).

Involvement in part-time contracts has affected the probabilities of transitions from employment and inactivity. The effects on transitions from employment during the period 2011 - 2014 have been stronger than the effects that took place in the years $2008-2011$. The chances of part-time workers to remain in work were 7.4 percentage points higher and the chances to move to inactivity were 5.1 percentage points lower as compared to full-time workers. On the other hand, while experience with part-time work affected positively the job prospects of unemployed persons during the crisis years, such effect did not appear in the period $2011-2014$.

\footnotetext{
${ }^{9}$ We calculated intervals \pm 2 standard deviations around the estimates in order to determine whether there are significant differences (in the case the intervals overlap). All calculations are available upon requests from authors.
} 
The role of occupation has also changed to a certain extent. Firstly, the effects of occupational categories on the transitions from employment have changed direction. During the crisis years, workers in lower occupational categories showed higher probabilities to stay in work and lower probabilities to move to unemployment and inactivity. After the crisis years, the opposite has become true. In addition, the magnitude of the effects has decreased. It suggests that although the overall situation in the labour market has not improved markedly, jobs for higher occupational classes, including jobs as managers and professionals, have started to offer better future prospects. However, the relative position of members of the highest occupational category was worse in terms of transitions from unemployment. They had lowest chances to find a job - all other occupational categories showed higher unemployment-to-employment transition rates. They also had a worse position when it came to the transition from unemployment to inactivity and the inability to escape unemployment. In general, contrary to the period $2008-2011$, the type of occupation has contributed significantly to the transitions from unemployment during the years $2011-2014$.

The occupation effects on the transitions from inactivity retain its direction and significance. This means that inactive persons who previously worked in high-level occupations showed the lowest probability to move into employment or unemployment in both the crisis and pre-crisis period. Further, in both periods they were more likely to stay inactive, as compared to other occupational groups. What has changed is the magnitude of the effects. It has decreased for all transitions from inactivity and for all occupational categories.

Work intensity has remained an important driver of transition probabilities in the period from 2011 to 2014 . Workers living in the households characterised by low work intensity had the worse prospects in the labour markets, unemployed persons from such households had the worse prospects to escape unemployment and inactive persons the worse chances to move to unemployment and employment. Moreover, the impact of work intensity increased in the period from 2011 to 2014. This was particularly true for the transitions of workers.

After the crisis, the men's chances for success in the labour market increased - they have experienced an increase in the probability of staying employed, moving from unemployment to employment and a decline in the probability of moving from employment to unemployment and inactivity.

The role of health status has remained more or less same, with one important exception. Inactive people with poorer health status have become more immobile compared to inactive persons with better health. While during the crisis years they were 2.8 percentage points more likely to stay inactive than persons with "optimal" health, after the crisis this difference has increased to 4.1 percentage points. 


\section{Discussion and Conclusion}

Previous research showed that Central European countries had low rates of labour market transitions prior to and during the crisis (Garda, 2016; RWI, 2014). Our results confirm this tendency. Shorrock's index reached the value of 0.226 during the recession, which was below the values in the majority of other EU countries. After the crisis, the overall mobility has further decreased, as indicated by drop in the value of Shorrock's index (0.193).

Lower labour market mobility after the recession stem from the increased rate of reproduction of labour market statuses, with the strongest growth of immobility among unemployed.

An interesting finding is that the labour market mobility in Slovakia has been comparatively low in the three different periods: in the times of strong economic and employment growth between the years 2005 and 2008 (which resulted from the series of welfare state reforms and favourable international economic conditions), during the crisis years and years after the crisis. It seems that there is some kind of path dependence, inheritance, which contributes to avoiding any increase in the overall extent of transitions between different labour market statuses. However, it is not clear what kinds of factors lie behind this result. A specificity of the labour market's institutional framework, often presented as one of the factor of transitions' variability (Garda, 2016), does not seem to play a role because the degree of the labour market regulation varies across the three periods. While quite strong before 2005, the rigidness of the labour market and the degree of its regulation declined significantly between 2005 and 2008. As a result, they cannot account for the persisting low labour market mobility. Impact of other factors - generous unemployment benefits and higher spending on the active labour market policies (Garda, 2016) - can be ruled out as Slovakia belongs to the less generous countries.

The post-crisis period has brought a fluctuation in employment and unemployment rates. In terms of the transition probabilities (averaged for the given period), two major shifts occurred. In addition to the increased reproduction rate of the labour market statuses, which represented the main feature of this period, transitions from unemployment to employment declined significantly. Taking into account that the profile of transitions from inactivity has changed only to a limited extent, it was the increased reproduction of unemployment and decreased outflows from unemployment to employment, which contributed most to the changing profile between the crisis and the post-crisis periods.

Our regression analyses offer new insights into the role of the micro-level determinants. They confirm the important role of education. Better-educated workers had better job prospects during the crisis. This effect has disappeared 
after the crisis. Labour market trajectories of workers during the years after the crisis have no longer been dependent on the level of education. Increased stability of employment has gone hand in hand with disappearance of the education's effect. However, education has continued to play an important role in terms of transitions from unemployment.

The important factors, identified by the study, include work experience, type of contract, occupational category, as well as work intensity. Their effects reveal a lot about the nature of the crisis and path to recovery. Length of work experience increased labour market chances of unemployed persons and this effect became stronger after the crisis. Part-time contracts brought a greater stability of jobs, in particular in the post-crisis period.

On the other hand, in this period, the positive effect on the job prospects of unemployed persons disappeared. The crisis years conferred advantage to people in low-level occupations. When the crisis has gone away, "better" jobs have become a stronger source of job stability and better job prospects. A strong relationship between work intensity and labour market transitions, which was identified in both periods, confirms that labour market chances are unevenly distributed across various socio-economic contexts. Living in household where nobody works reduced chances to find or keep a job. This finding opens the questions about the role of the educational homogamy and assortative mating, which should become an object of further research.

In addition to the above-mentioned factors and control variables, we also employ region and degree of urbanization. Although they do not show strong effects, their incorporation is important as it allows us to control for spatial differences in the labour market outcomes that are quite large in Slovakia.

Our analysis shows that low labour market mobility may hide significant differences in the probability of changing labour market status. Unfortunately, we could not test all the desired factors due to data limitations. We have had to omit the important characteristics of job security - information whether there is temporary or permanent contract.

The Slovak longitudinal EU-SILC datasets do not contain sufficient numbers of cases for such purpose. The fact that the longitudinal datasets contain less information as compared to the cross-sectoral ones limits the complexity of our models. It is reasonable to suppose that the situation would be even worse in case of cross-country comparison.

The analysis provides some food for thought for the next research on the labour market transitions both in the Central Europe territory and in the EU as a whole. One of the future steps should involve comparison of more periods in order to track long-term trends. 


\section{References}

BACHMANN, R. - BECHARA, P. - KRAMER, A. - RZEPKA, S. (2015): Labour Market Dynamics and Worker Heterogeneity during the Great Recession - Evidence from Europe. IZA Journal of European Labour Studies, 4, No. 19 (open access).

BERGIN, A. - KELLY, E. - MCGUINNESS, S. (2015): Changes in Labour Market Transitions in Ireland over the Great Recession: What Role for Policy? IZA Journal of European Labour Studies, 4, No. 9 (open access).

D'APICE, P. (2014): The Slovak Labour Market in the Wake of the Cisis: Did Okun's Law Hold? ECFIN Country Focus, 4, No. 4.

ERNST, E. - RANI, U. (2011): Understanding Unemployment Flows. Oxford Review of Economic Policy, 27, No. 2, pp. $268-294$.

EUROPEAN COMMISSION (2016): Labour Market Transitions. [Analytical Web Note 1/2016.] Brussels: European Commission.

EUROPEAN COMMISSION (2019): Country Report Slovakia 2019. [Commission Staff Working Document.] Brussels: European Commission.

EUROSTAT (2017): Methodological Guidelines and Description of EU-SILC Target Variables. DocSILC065 (2016 operation): Luxembourg: Eurostat.

FLEK, V. - MYSÍKOVÁ, M. (2015): Unemployment Dynamics in Central Europe: A Labour Flow Approach. Prague Economic Papers, 24, No. 1, pp. 73 - 87.

GARDA, P. (2016): The Ins and Outs out of Employment in 25 OECD Countries. [OECD Economic Department Working Papers, No. 1350.] Paris: OECD Publishing.

HVOZDÍKOVÁ, V. - STUDENÁ, I. (2016): Key Developments in Slovak Labour Market Indicators. In: LUBYOVÁ, M. and ŠTEFÁNIK, M. (eds): Labour Market in Slovakia 2017+. Bratislava: Institute of Economic Research, Slovak Academy of Sciences, pp. 7 - 44.

LEHMANN, N. - RAZZOLINI, T. - ZAICEVA, A. (2015): Worker Flows and Labour Market Adjustment during the Great Recession: Evidence from a Large Shock. [IZA Discussion Paper, No. 9588.] Bonn: Institute for the Study of Labour.

MORTENSEN, D. T. - PISSARIDES, C. A. (1994): Job Creation and Job Destruction in the Theory of Unemployment. Review of Economic Studies, 61, No. 3, pp. $397-415$.

MORTENSEN, D. T. - PISSARIDES, C. A. (1999): New Developments in Models of Search in the Labour Market. [Discussion Paper, No. 2053.] London: Centre for Economic Policy Research.

OECD (2012): OECD Economic Surveys: Slovak Republic 2012. Paris: OECD Publishing.

RWI (2014): A Study on Labour Market Transitions Using Micro-data from the Statistics on Income and Living Conditions. [Final Report.] Essen: Rheinisch-Westfällisches Institut fur Wirtschaftsforschung.

ŠTEFÁNIK, M. et al. (2018): Labour Market in Slovakia 2019+. Bratislava: Institute of Economic Research, Slovak Academy of Sciences.

WARD-WARMEDINGER, M. - MACCHIARELLI, C. (2014): Transitions in Labour Market Status in EU Labour Markets. IZA Journal of European Labour Studies, 3, No. 17 (open access).

WULFF, J. N. (2015): Interpreting Results from the Multinomial Logit Model: Demonstrated by Foreign Market Entry. Organizational Research Methods, 18, No. 2, pp. 300 - 325. 


\section{A n n e x}

Table A1

Transitions from Employment to Different Labour Market Statuses in the Period $2007-2011$

\begin{tabular}{|c|c|c|c|c|c|c|}
\hline & \multicolumn{2}{|c|}{ Employment } & \multicolumn{2}{|c|}{ Unemployment } & \multicolumn{2}{|c|}{ Inactivity } \\
\hline & Marg. effect & S.E. & Marg. effect & S.E. & Marg. effect & S.E. \\
\hline \multicolumn{7}{|l|}{ Sex } \\
\hline Female & \multicolumn{2}{|c|}{ Reference category } & \multicolumn{2}{|c|}{ Reference category } & \multicolumn{2}{|c|}{ Reference category } \\
\hline Male & $0.019 * * *$ & 0.001 & $0.004 * * *$ & 0.000 & $-0.022 * * *$ & 0.001 \\
\hline \multicolumn{7}{|l|}{ Age } \\
\hline Age $15-24$ & \multicolumn{2}{|c|}{ Reference category } & \multicolumn{2}{|c|}{ Reference category } & \multicolumn{2}{|c|}{ Reference category } \\
\hline Age $25-34$ & -0.004 & 0.003 & $0.009^{* * *} *$ & 0.002 & $-0.005^{* *}$ & 0.002 \\
\hline Age $35-44$ & $-0.019 * * *$ & 0.003 & $0.039 * * *$ & 0.002 & $-0.020^{* * *}$ & 0.002 \\
\hline Age $45-54$ & $-0.006^{*}$ & 0.003 & $0.037 * * * *$ & 0.002 & -0.031 *** & 0.002 \\
\hline Age $55-64$ & $0.012 * * *$ & 0.003 & -0.001 & 0.003 & $-0.011 * * *$ & 0.002 \\
\hline \multicolumn{7}{|l|}{ Education } \\
\hline Low & \multicolumn{2}{|c|}{ Reference category } & \multicolumn{2}{|c|}{ Reference category } & \multicolumn{2}{|c|}{ Reference category } \\
\hline Medium & $0.040^{* * *}$ & 0.003 & $-0.017 * * *$ & 0.002 & $-0.023^{* * *}$ & 0.002 \\
\hline High & $0.087 * * * *$ & 0.003 & $-0.054 * * *$ & 0.002 & -0.034 *** & 0.002 \\
\hline \multicolumn{7}{|l|}{ Health } \\
\hline \multirow{2}{*}{$\begin{array}{l}\text { Suboptimal } \\
\text { Optimal }\end{array}$} & \multicolumn{2}{|c|}{ Reference category } & Referenc & tegory & Referenc & egory \\
\hline & $0.019 * * *$ & 0.001 & $-0.008^{* * *}$ & 0.001 & $-0.012 * * *$ & 0.001 \\
\hline Children & & & & & & \\
\hline No children & Referenc & tegory & Referenc & tegory & Referenc & egory \\
\hline $1-2$ children & $0.013 * * *$ & 0.001 & $-0.012 * * *$ & 0.001 & -0.001 & 0.001 \\
\hline $3+$ children & 0.004 & 0.003 & -0.028 *** & 0.002 & $0.025 * * *$ & 0.002 \\
\hline Marital status & & & & & & \\
\hline Single & Referenc & tegory & Referenc & tegory & Referenc & egory \\
\hline Married & $0.006^{* *}$ & 0.003 & $-0.014^{* * *}$ & 0.002 & $0.008^{* * * *}$ & 0.002 \\
\hline Another status & $0.006 * *$ & 0.002 & $-0.015^{* * * *}$ & 0.002 & $0.009 * * *$ & 0.002 \\
\hline Partnership & & & & & & \\
\hline Without partner & Referenc & tegory & Referenc & tegory & Referenc & egory \\
\hline With partner & $-0.014 * * *$ & 0.003 & $-0.004 *$ & 0.002 & $0.017 * * *$ & 0.002 \\
\hline Contract & & & & & & \\
\hline Full time & Referenc & tegory & Referenc & tegory & Referenc & egory \\
\hline Part-time & $0.024 * * *$ & 0.004 & $0.010 * * *$ & 0.003 & $-0.034 * * *$ & 0.004 \\
\hline Working years & & & & & & \\
\hline 5 years or less & Referenc & tegory & Referenc & tegory & Referenc & egory \\
\hline $6-10$ years & $0.029 * * *$ & 0.002 & $-0.026^{* * *}$ & 0.002 & $-0.003^{*}$ & 0.002 \\
\hline $11-15$ years & $0.045^{* * * *}$ & 0.003 & $-0.031^{* * *}$ & 0.002 & $-0.013^{* * *}$ & 0.002 \\
\hline 16 years or more & $0.083 * * *$ & 0.003 & $-0.054 * * *$ & 0.002 & $-0.029 * * *$ & 0.002 \\
\hline Occupation & & & & & & \\
\hline ISCO $1-3$ & Referenc & tegory & Referenc & tegory & Referenc & egory \\
\hline ISCO $4-5$ & $0.091 * * * *$ & 0.003 & $-0.028^{*} * *$ & 0.002 & -0.064 *** & 0.003 \\
\hline ISCO $6-8$ & $0.108 * * *$ & 0.003 & $-0.034^{* * *}$ & 0.002 & $-0.074^{* * * *}$ & 0.003 \\
\hline ISCO 9 & $0.167 * * *$ & 0.012 & $-0.046^{* * *}$ & 0.005 & $-0.121^{* * * *}$ & 0.014 \\
\hline Work intensity & & & & & & \\
\hline Low & Referenc & tegory & Referenc & tegory & Referenc & egory \\
\hline Medium & $0.077 * * *$ & 0.002 & $-0.033^{* * *}$ & 0.001 & $-0.044^{*} * *$ & 0.001 \\
\hline High & $0.190^{* * * *}$ & 0.002 & $-0.098 * * *$ & 0.002 & $-0.092 * * *$ & 0.002 \\
\hline Degree of urbani & & & & & & \\
\hline Low & Referenc & tegory & Referenc & tegory & Referenc & egory \\
\hline Medium & $0.012 * * *$ & 0.001 & $-0.004^{*} * *$ & 0.001 & $-0.009^{* * *}$ & 0.001 \\
\hline High & 0.002 & 0.001 & 0.001 & 0.001 & $-0.003^{* * *} *$ & 0.001 \\
\hline Region & & & & & & \\
\hline Bratislava region & $0.006 * *$ & 0.002 & $-0.010^{* * * *}$ & 0.002 & $0.005^{* * *} *$ & 0.002 \\
\hline West Slovakia & $-0.005^{* * *}$ & 0.001 & 0.002 & 0.001 & $0.003 * *$ & 0.001 \\
\hline Central Slovakia & Referenc & tegory & Referenc & egory & Referenc & egory \\
\hline East Slovakia & $0.004 * *$ & 0.002 & $-0.002 *$ & 0.001 & -0.002 & 0.001 \\
\hline Years dummies & Inc & & Inc & & Inc & \\
\hline
\end{tabular}

Notes: Pseudo $\mathrm{R}^{2}=0.408$, Number of observations $=119,853$.

Source: EU-SILC 2009 - 2012 and 2012 - 2015, authors' calculations. 
Table A2

Transitions from Unemployment to Different Labour Market Statuses in the Period $2007-2011$

\begin{tabular}{|c|c|c|c|c|c|c|}
\hline & \multicolumn{2}{|c|}{ Employment } & \multicolumn{2}{|c|}{ Unemployment } & \multicolumn{2}{|c|}{ Inactivity } \\
\hline & Marg. effect & S.E. & Marg. Effect & S.E. & Marg. effect & S.E. \\
\hline \multicolumn{7}{|l|}{ Sex } \\
\hline \multirow{2}{*}{$\begin{array}{l}\text { Female } \\
\text { Male }\end{array}$} & \multicolumn{2}{|c|}{ Reference category } & \multicolumn{2}{|c|}{ Reference category } & \multicolumn{2}{|c|}{ Reference category } \\
\hline & $0.020^{* * * *}$ & 0.006 & $0.040 * * *$ & 0.007 & $-0.061 * * *$ & 0.005 \\
\hline \multicolumn{7}{|l|}{ Age } \\
\hline Age $15-24$ & \multicolumn{2}{|c|}{ Reference category } & \multicolumn{2}{|c|}{ Reference category } & \multicolumn{2}{|c|}{ Reference category } \\
\hline Age $25-34$ & $0.035^{* * * *}$ & 0.008 & $0.034 * * *$ & 0.010 & $-0.069 * * *$ & 0.007 \\
\hline Age $35-44$ & $0.043 * * *$ & 0.014 & $0.135^{* * *}$ & 0.017 & $-0.179 * * *$ & 0.012 \\
\hline Age $45-54$ & -0.020 & 0.015 & $0.181 * * *$ & 0.019 & $-0.161 * * *$ & 0.013 \\
\hline Age $55-64$ & -0.009 & 0.017 & $0.093 * * *$ & 0.021 & $-0.084 * * *$ & 0.014 \\
\hline \multicolumn{7}{|l|}{ Education } \\
\hline Low & \multicolumn{2}{|c|}{ Reference category } & \multicolumn{2}{|c|}{ Reference category } & \multicolumn{2}{|c|}{ Reference category } \\
\hline Medium & $0.036^{*} * *$ & 0.009 & $-0.062 * * *$ & 0.011 & $0.026^{* * *}$ & 0.006 \\
\hline High & $0.161 * * *$ & 0.011 & $-0.211 * * *$ & 0.014 & $0.050 * * *$ & 0.009 \\
\hline \multicolumn{7}{|l|}{ Health } \\
\hline \multirow{2}{*}{$\begin{array}{l}\text { Suboptimal } \\
\text { Optimal }\end{array}$} & Referenc & tegory & Referenc & tegory & Referenc & egory \\
\hline & $0.016^{* * *}$ & 0.007 & $0.027 * * *$ & 0.008 & $-0.043 * * *$ & 0.005 \\
\hline Children & & & & & & \\
\hline No children & Referenc & egory & Referenc & tegory & Referenc & egory \\
\hline $1-2$ children & $0.017 * * *$ & 0.006 & $-0.049 * * *$ & 0.007 & $0.032 * * *$ & 0.005 \\
\hline $3+$ children & 0.037 *** & 0.012 & $-0.082 * * *$ & 0.013 & $0.045 * * *$ & 0.008 \\
\hline Marital status & & & & & & \\
\hline Single & Referenc & egory & Referenc & tegory & Referenc & egory \\
\hline Married & 0.019 & 0.017 & $-0.040 * *$ & 0.019 & $0.022 *$ & 0.012 \\
\hline Another status & $0.059 * * *$ & 0.013 & $-0.048 * * *$ & 0.015 & -0.010 & 0.010 \\
\hline Partnership & & & & & & \\
\hline Without partner & Referenc & tegory & Referenc & tegory & Referenc & egory \\
\hline With partner & $-0.031 * *$ & 0.015 & 0.001 & 0.018 & $0.030^{* * * *}$ & 0.011 \\
\hline Contract & & & & & & \\
\hline Full time & Referenc & egory & Referenc & tegory & Referenc & egory \\
\hline Part-time & $0.076^{* * * *}$ & 0.014 & $-0.045 * * *$ & 0.028 & -0.031 *** & 0.026 \\
\hline Working years & & & & & & \\
\hline 5 years or less & Referenc & tegory & Referenc & tegory & Referenc & egory \\
\hline $6-10$ years & 0.008 & 0.012 & $-0.046 * * *$ & 0.015 & $0.038^{* * *} *$ & 0.010 \\
\hline $11-15$ years & $0.052 * * *$ & 0.013 & $-0.086^{* * *}$ & 0.017 & $0.034 * * *$ & 0.012 \\
\hline 16 years or more & 0.082 *** & 0.013 & $-0.127 * * *$ & 0.016 & $0.045^{* * *}$ & 0.011 \\
\hline Occupation & & & & & & \\
\hline ISCO $1-3$ & Referenc & tegory & Referenc & tegory & Referenc & egory \\
\hline ISCO $4-5$ & $0.271^{* * * *}$ & 0.008 & $-0.168 * * *$ & 0.017 & $-0.104 * * *$ & 0.017 \\
\hline ISCO $6-8$ & 0.415 & 4.771 & 0.650 & 30.556 & -1.065 & 35.337 \\
\hline ISCO 9 & 0.520 & 8.708 & 0.527 & 55.791 & -1.046 & 64.498 \\
\hline Work intensity & & & & & & \\
\hline Low & Referenc & tegory & Referenc & tegory & Referenc & egory \\
\hline Medium & $0.276^{* * *}$ & 0.015 & $-0.220 * * *$ & 0.014 & $-0.056 * * *$ & 0.006 \\
\hline High & 0.488 *** $*$ & 0.013 & $-0.420 * * *$ & 0.014 & $-0.069 * * *$ & 0.006 \\
\hline Degree of urban & & & & & & \\
\hline Low & Referenc & egory & Referenc & tegory & Referenc & egory \\
\hline Medium & -0.005 & 0.006 & 0.001 & 0.007 & 0.004 & 0.005 \\
\hline High & $0.036^{* * * *}$ & 0.007 & $-0.039 * * *$ & 0.009 & 0.003 & 0.006 \\
\hline Region & & & & & & \\
\hline Bratislava region & 0.091 *** & 0.014 & $-0.171 * * *$ & 0.017 & $0.081^{* * * *}$ & 0.010 \\
\hline West Slovakia & 0.003 & 0.007 & $-0.015^{*}$ & 0.009 & $0.012^{* *}$ & 0.006 \\
\hline Central Slovakia & Referenc & egory & Referenc & tegory & Referenc & egory \\
\hline East Slovakia & 0.005 & 0.007 & 0.005 & 0.008 & -0.009 & 0.006 \\
\hline Years dummies & Inc & & Inc & & Inc & \\
\hline
\end{tabular}

Notes: Pseudo $\mathrm{R}^{2}=0.402$, Number of observations $=14,220$.

Source: EU-SILC 2009 - 2012 and 2012 - 2015, authors' calculations. 
T a ble A3

Transitions from Inactivity to Different Labour Market Statuses in the Period $2007-2011$

\begin{tabular}{|c|c|c|c|c|c|c|}
\hline & \multicolumn{2}{|c|}{ Employment } & \multicolumn{2}{|c|}{ Unemployment } & \multicolumn{2}{|c|}{ Inactivity } \\
\hline & Marg. effect & S.E. & Marg. Effect & S.E. & Marg. effect & S.E. \\
\hline \multicolumn{7}{|l|}{ Sex } \\
\hline Female & \multicolumn{2}{|c|}{ Reference category } & \multicolumn{2}{|c|}{ Reference category } & \multicolumn{2}{|c|}{ Reference category } \\
\hline Male & $-0.003^{* * *}$ & 0.001 & $-0.001 * * *$ & 0.001 & $-0.003^{* * * *}$ & 0.001 \\
\hline \multicolumn{7}{|l|}{ Age } \\
\hline Age $15-24$ & \multicolumn{2}{|c|}{ Reference category } & \multicolumn{2}{|c|}{ Reference category } & \multicolumn{2}{|c|}{ Reference category } \\
\hline Age $25-34$ & $0.029 * * *$ & 0.001 & $0.017 * * *$ & 0.001 & $-0.045^{* * *}$ & 0.002 \\
\hline Age $35-44$ & $0.032 * * *$ & 0.002 & $0.033 * * *$ & 0.002 & $-0.066^{* * *}$ & 0.003 \\
\hline Age $45-54$ & 0.032 & 0.003 & $0.020 * * *$ & 0.003 & $-0.024 * * *$ & 0.004 \\
\hline Age $55-64$ & $0.006^{*}$ & 0.003 & 0.000 & 0.003 & -0.006 & 0.004 \\
\hline \multicolumn{7}{|l|}{ Education } \\
\hline Low & \multicolumn{2}{|c|}{ Reference category } & \multicolumn{2}{|c|}{ Reference category } & \multicolumn{2}{|c|}{ Reference category } \\
\hline Medium & $0.038 * * *$ & 0.003 & $0.043 * * *$ & 0.002 & $-0.081^{* * *}$ & 0.003 \\
\hline High & $0.052 * * *$ & 0.003 & $0.037 * * *$ & 0.002 & $-0.088^{* * *}$ & 0.003 \\
\hline \multicolumn{7}{|l|}{ Health } \\
\hline Suboptimal & \multicolumn{2}{|c|}{ Reference category } & \multicolumn{2}{|c|}{ Reference category } & Referenc & egory \\
\hline Optimal & $0.017 * * *$ & 0.002 & $0.011 * * *$ & 0.002 & $-0.028^{* * *}$ & 0.002 \\
\hline Children & & & & & & \\
\hline No children & Referenc & egory & Referenc & tegory & Referenc & egory \\
\hline $1-2$ children & $-0.007 * * *$ & 0.001 & $-0.007 * * *$ & 0.001 & $0.014 * * *$ & 0.002 \\
\hline $3+$ children & $-0.005^{* *}$ & 0.002 & $-0.033 * * *$ & 0.003 & $0.037 * * *$ & 0.003 \\
\hline Marital status & & & & & & \\
\hline Single & Reference cate & & Reference cate & & Reference cate & \\
\hline Married & -0.003 & 0.003 & $-0.009 * *$ & 0.004 & $0.012 * *$ & 0.005 \\
\hline Another status & 0.002 & 0.003 & -0.001 & 0.003 & -0.001 & 0.004 \\
\hline Partnership & & & & & & \\
\hline Without partner & Reference cate & & Reference cate & & Reference cate & \\
\hline With partner & $0.006^{* *}$ & 0.003 & 0.005 & 0.004 & $-0.011^{* *}$ & 0.004 \\
\hline Contract & & & & & & \\
\hline Full time & Referenc & tegory & Referenc & tegory & Referenc & egory \\
\hline Part-time & & & $0.011 * * *$ & 0.003 & $-0.040^{* * *}$ & 0.004 \\
\hline Working years & & & & & & \\
\hline 5 years or less & Referenc & egory & Referenc & tegory & Referenc & egory \\
\hline $6-10$ years & $0.005^{* *}$ & 0.002 & $-0.020^{* * *}$ & 0.003 & $0.015^{* * *}$ & 0.003 \\
\hline $11-15$ years & $0.017 * * *$ & 0.003 & $-0.028^{* * *} *$ & 0.004 & $0.012 * * *$ & 0.004 \\
\hline 16 years or more & $0.021 * * *$ & 0.003 & $-0.049 * * *$ & 0.003 & $0.029 * * *$ & 0.004 \\
\hline Occupation & & & & & & \\
\hline ISCO $1-3$ & Referenc & egory & Referenc & tegory & Referenc & egory \\
\hline ISCO $4-5$ & $0.073^{*} * *$ & 0.002 & $0.029 * * *$ & 0.003 & $-0.103^{* * *}$ & 0.003 \\
\hline ISCO $6-8$ & $0.069 * * *$ & 0.002 & $0.035 * * *$ & 0.003 & $-0.104^{* * * *}$ & 0.004 \\
\hline ISCO 9 & $0.124 * * *$ & 0.005 & $0.067 * * *$ & 0.007 & $-0.191 * * *$ & 0.011 \\
\hline Work intensity & & & & & & \\
\hline Low & Referenc & egory & Referenc & tegory & Referenc & egory \\
\hline Medium & $0.035 * * *$ & 0.003 & $0.016^{* * *}$ & 0.002 & $-0.051 * * *$ & 0.003 \\
\hline High & $0.094 * * *$ & 0.003 & 0.002 & 0.002 & $-0.096^{* * * *}$ & 0.003 \\
\hline Degree of urban & & & & & & \\
\hline Low & Referenc & egory & Referenc & tegory & Referenc & egory \\
\hline Medium & $-0.002 * *$ & 0.001 & $-0.007 * * *$ & 0.001 & $0.009 * * *$ & 0.001 \\
\hline High & $-0.004 * * *$ & 0.001 & $-0.008 * * *$ & 0.001 & $0.012 * * *$ & 0.002 \\
\hline Region & & & & & & \\
\hline Bratislava region & $0.005^{* * *}$ & 0.002 & $-0.005^{* *}$ & 0.002 & $-0.001^{* * * *}$ & 0.003 \\
\hline West Slovakia & -0.002 & 0.001 & $-0.002^{*}$ & 0.001 & $0.004 * *$ & 0.002 \\
\hline Central Slovakia & Referenc & tegory & Referenc & tegory & Referenc & egory \\
\hline East Slovakia & $0.005^{* * *}$ & 0.001 & $-0.008 * * *$ & 0.001 & 0.003 & 0.002 \\
\hline Years dummies & Incl & & Incl & & Inc & \\
\hline
\end{tabular}

Notes: Pseudo $\mathrm{R}^{2}=0.427$, Number of observations $=101,331$.

Source: EU-SILC 2009 - 2012 and 2012 - 2015, authors' calculations. 
Table A4

Transitions from Employment to Different Labour Market Statuses in the Period 2011 - 2014

\begin{tabular}{|c|c|c|c|c|c|c|}
\hline & \multicolumn{2}{|c|}{ Employment } & \multicolumn{2}{|c|}{ Unemployment } & \multicolumn{2}{|c|}{ Inactivity } \\
\hline & Marg. effect & S.E. & Marg. Effect & S.E. & Marg. effect & S.E. \\
\hline \multicolumn{7}{|l|}{ Sex } \\
\hline Female & \multicolumn{2}{|c|}{ Reference category } & \multicolumn{2}{|c|}{ Reference category } & \multicolumn{2}{|c|}{ Reference category } \\
\hline Male & $0.038 * * *$ & 0.001 & 0.001 & 0.001 & $-0.038 * * *$ & 0.001 \\
\hline \multicolumn{7}{|l|}{ Age } \\
\hline Age $15-24$ & \multicolumn{2}{|c|}{ Reference category } & \multicolumn{2}{|c|}{ Reference category } & \multicolumn{2}{|c|}{ Reference category } \\
\hline Age $25-34$ & $-0.008 * *$ & 0.003 & 0.020 *** & 0.002 & $-0.012 * * *$ & 0.002 \\
\hline Age $35-44$ & $-0.009 * * *$ & 0.003 & $0.037 * * *$ & 0.002 & $-0.028 * * *$ & 0.002 \\
\hline Age $45-54$ & 0.005 & 0.004 & $0.043 * * *$ & 0.002 & $-0.048 * * *$ & 0.003 \\
\hline Age $55-64$ & $0.034 * * *$ & 0.003 & $-0.016^{* * *}$ & 0.002 & $-0.019 * * *$ & 0.002 \\
\hline \multicolumn{7}{|l|}{ Education } \\
\hline Low & \multicolumn{2}{|c|}{ Reference category } & \multicolumn{2}{|c|}{ Reference category } & \multicolumn{2}{|c|}{ Reference category } \\
\hline Medium & -0.001 & 0.003 & $0.009 * * *$ & 0.002 & $-0.008^{* * *}$ & 0.002 \\
\hline High & $0.006^{*}$ & 0.003 & -0.007 & 0.002 & $-0.006^{* *}$ & 0.002 \\
\hline \multicolumn{7}{|l|}{ Health } \\
\hline Suboptimal & \multicolumn{2}{|c|}{ Reference category } & \multicolumn{2}{|c|}{ Reference category } & Referenc & egory \\
\hline Optimal & $0.019 * * *$ & 0.001 & $-0.004 * * *$ & 0.001 & $-0.015^{* * * *}$ & 0.001 \\
\hline Children & & & & & & \\
\hline No children & Referenc & tegory & Referenc & tegory & Referenc & egory \\
\hline $1-2$ children & $0.011 * * *$ & 0.002 & $-0.012 * * *$ & 0.001 & 0.001 & 0.001 \\
\hline $3+$ children & $-0.008 * *$ & 0.003 & $-0.032 * * *$ & 0.003 & $0.039 * * *$ & 0.002 \\
\hline Marital status & & & & & & \\
\hline Single & Reference cate & & Reference cate & & Reference cate & \\
\hline Married & $-0.011 * * *$ & 0.003 & $-0.004 * *$ & 0.002 & $0.015^{* * *} *$ & 0.002 \\
\hline Another status & $-0.004 *$ & 0.002 & $-0.003 * *$ & 0.002 & $0.007 * * *$ & 0.002 \\
\hline Partnership & & & & & & \\
\hline Without partner & Referenc & tegory & Referenc & tegory & Referenc & egory \\
\hline With partner & $-0.005^{* *}$ & 0.003 & $-0.005^{* * *}$ & 0.002 & $0.011^{*} * *$ & 0.002 \\
\hline Contract & & & & & & \\
\hline Full time & Referenc & tegory & Referenc & tegory & Referenc & egory \\
\hline Part-time & $0.073^{* * *}$ & 0.005 & $-0.023^{* * *}$ & 0.003 & $-0.051 * * *$ & 0.004 \\
\hline Working years & & & & & & \\
\hline 5 years or less & Referenc & tegory & Referenc & tegory & Referenc & egory \\
\hline $6-10$ years & $0.027 * * *$ & 0.002 & $-0.012 * * *$ & 0.002 & $-0.015^{* * *}$ & 0.002 \\
\hline $11-15$ years & $0.044 * * *$ & 0.003 & $-0.029 * * *$ & 0.002 & $-0.016^{* * *}$ & 0.002 \\
\hline 16 years or more & $0.074 * * *$ & 0.003 & $-0.038 * * *$ & 0.002 & $-0.036^{* * * *}$ & 0.002 \\
\hline Occupation & & & & & & \\
\hline ISCO $1-3$ & Referenc & tegory & Referenc & tegory & Referenc & egory \\
\hline ISCO $4-5$ & $-0.006^{* * *}$ & 0.002 & 0.002 & 0.001 & $0.004 * * *$ & 0.001 \\
\hline ISCO $6-8$ & $-0.017 * * *$ & 0.002 & $0.011 * * *$ & 0.001 & $0.006^{* * * *}$ & 0.001 \\
\hline ISCO 9 & $-0.023 * * *$ & 0.002 & $0.022 * * *$ & 0.002 & 0.001 & 0.002 \\
\hline Work inten & & & & & & \\
\hline Low & Referenc & tegory & Referenc & egory & Referenc & egory \\
\hline Medium & $0.098 * * *$ & 0.002 & $-0.051 * * *$ & 0.002 & $-0.046^{* * *}$ & 0.002 \\
\hline High & $0.218^{* * * *}$ & 0.003 & $-0.106^{* * *}$ & 0.002 & $-0.112^{* * * *}$ & 0.002 \\
\hline Degree of urba & & & & & & \\
\hline Low & Referenc & tegory & Referenc & tegory & Referenc & egory \\
\hline Medium & $0.007 * * *$ & 0.001 & $-0.005^{* * *}$ & 0.001 & $-0.002 * *$ & 0.001 \\
\hline High & $0.007 * * *$ & 0.002 & $-0.007 * * *$ & 0.001 & 0.001 & 0.001 \\
\hline Region & & & & & & \\
\hline Bratislava region & $0.005^{* *}$ & 0.002 & $-0.005^{* * *}$ & 0.002 & -0.001 & 0.002 \\
\hline West Slovakia & $0.006^{* * *}$ & 0.001 & $-0.003 * * *$ & 0.001 & $-0.003 * *$ & 0.001 \\
\hline Central Slovakia & Referenc & tegory & Referenc & tegory & Referenc & egory \\
\hline East Slovakia & $0.016^{* * *}$ & 0.001 & $-0.006^{* * *}$ & 0.001 & $-0.011 * * *$ & 0.001 \\
\hline Years dummies & Incl & & Incl & & Incl & \\
\hline
\end{tabular}

Notes: Pseudo $\mathrm{R}^{2}=0.351$, Number of observations $=114,581$.

Source: EU-SILC 2009 - 2012 and 2012 - 2015, authors' calculations. 
Table A5

Transitions from Unemployment to Different Labour Market Statuses in the Period $2011-2014$

\begin{tabular}{|c|c|c|c|c|c|c|}
\hline & \multicolumn{2}{|c|}{ Employment } & \multicolumn{2}{|c|}{ Unemployment } & \multicolumn{2}{|c|}{ Inactivity } \\
\hline & Marg. effect & S.E. & Marg. Effect & S.E. & Marg. effect & S.E. \\
\hline \multicolumn{7}{|l|}{ Sex } \\
\hline Female & \multicolumn{2}{|c|}{ Reference category } & \multicolumn{2}{|c|}{ Reference category } & \multicolumn{2}{|c|}{ Reference category } \\
\hline Male & $0.046 * * *$ & 0.005 & -0.007 & 0.007 & $-0.039 * * *$ & 0.005 \\
\hline \multicolumn{7}{|l|}{ Age } \\
\hline Age $15-24$ & \multicolumn{2}{|c|}{ Reference category } & \multicolumn{2}{|c|}{ Reference category } & \multicolumn{2}{|c|}{ Reference category } \\
\hline Age $25-34$ & $-0.026 * * *$ & 0.008 & $0.059 * * *$ & 0.010 & -0.034 *** & 0.007 \\
\hline Age $35-44$ & $-0.121 * * *$ & 0.011 & $0.230 * * *$ & 0.015 & $-0.109 * * *$ & 0.011 \\
\hline Age $45-54$ & $-0.215^{* * *}$ & 0.015 & $0.327 * * *$ & 0.018 & $-0.111^{\text {**** }}$ & 0.013 \\
\hline Age $55-64$ & $-0.247 * * *$ & 0.016 & $0.250 * * *$ & 0.019 & -0.003 & 0.013 \\
\hline \multicolumn{7}{|l|}{ Education } \\
\hline Low & \multicolumn{2}{|c|}{ Reference category } & \multicolumn{2}{|c|}{ Reference category } & \multicolumn{2}{|c|}{ Reference category } \\
\hline Medium & $0.025^{* *}$ & 0.012 & $-0.056^{* * *}$ & 0.011 & $0.031 * * *$ & 0.006 \\
\hline High & $0.128 * * *$ & 0.013 & $-0.183^{* * *}$ & 0.014 & $0.055^{* * * *}$ & 0.008 \\
\hline \multicolumn{7}{|l|}{ Health } \\
\hline Suboptimal & \multicolumn{2}{|c|}{ Reference category } & \multicolumn{2}{|c|}{ Reference category } & Referenc & tegory \\
\hline Optimal & $0.018^{* * *}$ & 0.006 & $0.025^{* * * *}$ & 0.008 & $-0.044 * * *$ & 0.005 \\
\hline Children & & & & & & \\
\hline No children & Referenc & egory & Referenc & egory & Referenc & tegory \\
\hline $1-2$ children & $0.036^{* * *}$ & 0.005 & $-0.063^{* * *}$ & 0.007 & $0.028 * * *$ & 0.005 \\
\hline $3+$ children & 0.002 & 0.014 & $-0.078 * * *$ & 0.015 & 0.077 *** & 0.008 \\
\hline Marital status & & & & & & \\
\hline Single & Referenc & tegory & Referenc & tegory & Referenc & tegory \\
\hline Married & -0.012 & 0.012 & -0.013 & 0.014 & 0.039 *** & 0.009 \\
\hline Another status & $0.086^{* * *}$ & 0.011 & $-0.125^{* * *}$ & 0.013 & $0.025 * *$ & 0.008 \\
\hline Partnership & & & & & & \\
\hline Without partner & Referenc & egory & Referenc & tegory & Referenc & tegory \\
\hline With partner & 0.005 & 0.011 & -0.015 & 0.013 & 0.010 & 0.009 \\
\hline Contract & & & & & & \\
\hline Full time & Referenc & tegory & Referenc & tegory & Referenc & tegory \\
\hline Part-time & 0.312 & 4,001 & 0.710 & 28.279 & -1.022 & 32.380 \\
\hline Working years & & & & & & \\
\hline 5 years or less & Referenc & tegory & Referenc & tegory & Referenc & tegory \\
\hline $6-10$ years & $0.113^{* * *}$ & 0.009 & $-0.127 * * *$ & 0.013 & 0.014 & 0.010 \\
\hline $11-15$ years & $0.128^{* * *}$ & 0.012 & $-0.145^{* * *}$ & 0.015 & 0.017 & 0.010 \\
\hline 16 years or more & $0.197 * * *$ & 0.012 & $-0.196 * * *$ & 0.014 & 0.001 & 0.010 \\
\hline Occupation & & & & & & \\
\hline ISCO $1-3$ & Referenc & egory & Referenc & tegory & Referenc & tegory \\
\hline ISCO $4-5$ & $0.110^{* * * *}$ & 0.007 & $-0.078^{* * *}$ & 0.009 & $-0.032^{\text {**** }}$ & 0.006 \\
\hline ISCO $6-8$ & $0.131^{* * *}$ & 0.007 & $-0.086^{* * *}$ & 0.009 & $-0.046^{* * *}$ & 0.007 \\
\hline ISCO 9 & $0.104 * * *$ & 0.009 & $-0.048 * * *$ & 0.011 & $-0.057 * * *$ & 0.007 \\
\hline Work intensity & & & & & & \\
\hline Low & Referenc & tegory & Referenc & tegory & Referenc & tegory \\
\hline Medium & $0.206^{* * *}$ & 0.011 & $-0.169^{* * *}$ & 0.011 & $-0.036^{* * *}$ & 0.005 \\
\hline High & $0.458 * * *$ & 0.009 & $-0.398 * * *$ & 0.010 & $-0.061 * * *$ & 0.006 \\
\hline Degree of urbani & & & & & & \\
\hline Low & Referenc & tegory & Referenc & tegory & Referenc & tegory \\
\hline Medium & $0.027^{*} * *$ & 0.005 & -0.037 *** & 0.007 & $0.095 * *$ & 0.004 \\
\hline High & $0.040 * * *$ & 0.007 & $-0.037 * * *$ & 0.010 & -0.004 & 0.007 \\
\hline Region & & & & & & \\
\hline Bratislava region & 0.018 & 0.011 & $0.037 * * *$ & 0.017 & $-0.055^{\text {**** }}$ & 0.014 \\
\hline West Slovakia & $0.015 * *$ & 0.006 & $-0.034 * * *$ & 0.007 & 0.019 *** & 0.005 \\
\hline Central Slovakia & Referenc & egory & Referenc & egory & Referenc & tegory \\
\hline East Slovakia & -0.006 & 0.006 & $0.039 * * *$ & 0.007 & $-0.034 * * *$ & 0.005 \\
\hline Years dummies & Inc & & Inc & & Inc & \\
\hline
\end{tabular}

Notes: Pseudo $\mathrm{R}^{2}=0.350$, Number of observations $=17,102$.

Source: EU-SILC 2009 - 2012 and 2012 - 2015, authors' calculations. 
T a b le A6

Transitions from Inactivity to Different Labour Market Statuses in the Period 2011 - 2014

\begin{tabular}{|c|c|c|c|c|c|c|}
\hline & \multicolumn{2}{|c|}{ Employment } & \multicolumn{2}{|c|}{ Unemployment } & \multicolumn{2}{|c|}{ Inactivity } \\
\hline & Marg. effect & S.E. & Marg. Effect & S.E. & Marg. effect & S.E. \\
\hline \multicolumn{7}{|l|}{ Sex } \\
\hline Female & \multicolumn{2}{|c|}{ Reference category } & \multicolumn{2}{|c|}{ Reference category } & \multicolumn{2}{|c|}{ Reference category } \\
\hline Male & $0.006 * * *$ & 0.001 & $0.005 * * *$ & 0.001 & -0.011 **** & 0.001 \\
\hline \multicolumn{7}{|l|}{ Age } \\
\hline Age $15-24$ & \multicolumn{2}{|c|}{ Reference category } & \multicolumn{2}{|c|}{ Reference category } & \multicolumn{2}{|c|}{ Reference category } \\
\hline Age $25-34$ & $0.024 * * *$ & 0.001 & $0.019 * * *$ & 0.001 & $-0.043 * * *$ & 0.002 \\
\hline Age $35-44$ & $0.029 * * *$ & 0.002 & $0.028 * * *$ & 0.002 & -0.057 *** & 0.003 \\
\hline Age $45-54$ & 0.003 & 0.003 & $0.016^{* * *}$ & 0.004 & -0.019 *** & 0.004 \\
\hline Age $55-64$ & $-0.006 * * *$ & 0.003 & 0.001 & 0.003 & 0.005 & 0.004 \\
\hline \multicolumn{7}{|l|}{ Education } \\
\hline Low & \multicolumn{2}{|c|}{ Reference category } & \multicolumn{2}{|c|}{ Reference category } & \multicolumn{2}{|c|}{ Reference category } \\
\hline Medium & $0.051 * * *$ & 0.004 & $0.021 * * *$ & 0.002 & $-0.072^{*} * *$ & 0.004 \\
\hline High & $0.074 * * *$ & 0.004 & $0.013 * * *$ & 0.002 & $-0.087 * * *$ & 0.004 \\
\hline \multicolumn{7}{|l|}{ Health } \\
\hline Suboptimal & \multicolumn{2}{|c|}{ Reference category } & \multicolumn{2}{|c|}{ Reference category } & Referenc & egory \\
\hline Optimal & $0.022 * * *$ & 0.002 & $0.018^{* * *}$ & 0.002 & $-0.041 * * *$ & 0.002 \\
\hline Children & & & & & & \\
\hline No children & Referenc & tegory & Referenc & tegory & Referenc & egory \\
\hline $1-2$ children & $-0.006 * * *$ & 0.001 & $-0.008 * * *$ & 0.001 & $0.014 * * *$ & 0.002 \\
\hline $3+$ children & $-0.019 * * *$ & 0.002 & $-0.018 * * *$ & 0.003 & $0.037 * * *$ & 0.003 \\
\hline Marital status & & & & & & \\
\hline Single & Referenc & tegory & Referenc & tegory & Referenc & egory \\
\hline Married & $0.012 * * *$ & 0.003 & $-0.020^{* * *}$ & 0.003 & $0.008^{* *}$ & 0.004 \\
\hline Another status & $0.014 * * *$ & 0.003 & $-0.047 * * *$ & 0.005 & $0.033 * * *$ & 0.005 \\
\hline Partnership & & & & & & \\
\hline Without partner & Referenc & tegory & Referenc & tegory & Referenc & egory \\
\hline With partner & $-0.008^{* * *}$ & 0.002 & $0.007^{* * *} *$ & 0.003 & 0.001 & 0.003 \\
\hline Contract & & & & & & \\
\hline Full time & Referenc & tegory & Referenc & tegory & Referenc & egory \\
\hline Part-time & $0.058 * * *$ & 0.003 & $0.034 * * *$ & 0.004 & -0.093 *** & 0.005 \\
\hline Working years & & & & & & \\
\hline 5 years or less & Referenc & tegory & Referenc & tegory & Referenc & egory \\
\hline $6-10$ years & $0.016^{* * *}$ & 0.002 & $-0.030 * * *$ & 0.003 & $0.015^{* * *}$ & 0.003 \\
\hline $11-15$ years & 0.004 & 0.003 & $-0.037 * * *$ & 0.003 & $0.034 * * *$ & 0.004 \\
\hline 16 years or more & $0.009 * * *$ & 0.003 & $-0.057 * * *$ & 0.003 & $0.048^{* * *} *$ & 0.003 \\
\hline Occupation & & & & & & \\
\hline ISCO $1-3$ & Referenc & tegory & Referenc & tegory & Referenc & egory \\
\hline ISCO $4-5$ & $0.038 * * *$ & 0.001 & $0.017 * * *$ & 0.001 & $-0.055^{* * * *}$ & 0.002 \\
\hline ISCO $6-8$ & $0.039 * * *$ & 0.002 & $0.009 * * *$ & 0.002 & $-0.048^{* * * *}$ & 0.002 \\
\hline ISCO 9 & $0.051 * * *$ & 0.002 & $0.030 * * *$ & 0.002 & $-0.081^{* * * *}$ & 0.003 \\
\hline Work intens & & & & & & \\
\hline Low & Referenc & tegory & Referenc & tegory & Referenc & egory \\
\hline Medium & $0.032 * * *$ & 0.003 & $-0.008 * * *$ & 0.001 & $-0.024 * * *$ & 0.003 \\
\hline High & $0.110^{* * *}$ & 0.003 & $-0.016^{* * *}$ & 0.002 & $-0.094^{* * * *}$ & 0.003 \\
\hline Degree of urbar & & & & & & \\
\hline Low & Referenc & tegory & Referenc & tegory & Referenc & egory \\
\hline Medium & $0.002 * *$ & 0.001 & $-0.002 * *$ & 0.001 & 0.000 & 0.001 \\
\hline High & 0.001 & 0.001 & $-0.004 * * *$ & 0.001 & $0.003 *$ & 0.002 \\
\hline Region & & & & & & \\
\hline Bratislava region & $0.004 * *$ & 0.002 & $-0.006^{* * *}$ & 0.002 & 0.002 & 0.003 \\
\hline West Slovakia & 0.001 & 0.001 & $-0.005^{* * *}$ & 0.001 & $0.003^{* *} *$ & 0.002 \\
\hline Central Slovakia & Referenc & tegory & Referenc & tegory & Referenc & egory \\
\hline East Slovakia & $-0.003 * * *$ & 0.001 & -0.002 & 0.001 & $0.005^{* * *}$ & 0.002 \\
\hline Years dummies & Inc & & Incl & & Inc & \\
\hline
\end{tabular}

Notes: Pseudo $\mathrm{R}^{2}=0.420$, Number of observations $=102,401$.

Source: EU-SILC 2009 - 2012 and 2012 - 2015, authors' calculations. 